\title{
Controversies in the treatment of idiopathic membranous nephropathy
}

\author{
Meryl Waldman and Howard A. Austin III
}

\begin{abstract}
Optimum treatment of idiopathic membranous nephropathy is both controversial and challenging. The most extensively studied and frequently used immunosuppressive regimens for this disease comprise alkylating agents plus corticosteroids or ciclosporin. All of these treatment options have inherent problems: they are not effective in all patients, partial—rather than complete—remissions are common, adverse effects are worrisome, and relapses after treatment cessation remain problematic. Alternative immunosuppressive agents have been tested in an effort to overcome these unresolved issues. This paper reviews the available evidence regarding both established and new agents for the treatment of patients with idiopathic membranous nephropathy, with an emphasis on the results of the most recent clinical trials.
\end{abstract}

Waldman, M. \& Austin, H. A. III. Nat. Rev. Nephrol. 5, 469-479 (2009); published online 7 July 2009; doi:10.1038/nrneph.2009.101

\section{Introduction}

Membranous nephropathy accounts for about one-third of cases of adult-onset nephrotic syndrome. ${ }^{1,2}$ Renal biopsy typically reveals diffuse glomerular capillary wall thickening and subepithelial and/or intramembranous immune deposits. In developed countries, approximately $20 \%$ of cases are due to rheumatic, neoplastic or infectious diseases, medications or toxins $;^{3}$ in this article, however, we focus on idiopathic rather than secondary forms of the disease.

The nephrologist must consider several questions when faced with a patient who has a new diagnosis of idiopathic membranous nephropathy (IMN): should the patient be treated immediately? For how long should I observe the patient before deciding on management? What treatment should be given and for how long? These important and controversial questions do not have straightforward answers. Ultimately, decisions about treatment must integrate what is known about the individual patient with what is known about the risks and benefits of the available treatments and what is known about the natural history of this glomerular disease.

The goal of this Review is to provide an update on the treatment of IMN. Evidence from relatively recent trials is presented, with an emphasis on agents that have been studied as alternatives to cytotoxic drugs and ciclosporin. This article is not meant to be a comprehensive review of membranous nephropathy. We refer readers to several excellent publications and chapters which fulfill that purpose. ${ }^{4-6}$

\section{Who to treat}

Estimates of renal survival vary widely among published studies of IMN, which partly reflects differences

Competing interests

The authors declare no competing interests. in baseline prognostic features among the participants. Variation in the numbers of patients without the nephrotic syndrome enrolled in studies of the natural history of IMN makes it difficult to determine the renal prognosis of patients that do have this syndrome. To address this issue, du Buf-Vereijken et al. ${ }^{6}$ pooled data from 10 studies published over 25 years, excluding those with short follow-up, and calculated the risk of renal failure among patients with the nephrotic syndrome by assuming that renal survival was $100 \%$ in patients without this syndrome. Overall, nearly half of the patients with the nephrotic syndrome experienced marked declines in glomerular filtration rate (GFR). Without treatment, end-stage renal disease (ESRD) is estimated to occur in $10-30 \%$ of patients with IMN within 10 years. ${ }^{6-14}$ In a cohort from France ${ }^{15}$ that had median proteinuria of $6 \mathrm{~g}$ per day and median estimated GFR of $79 \mathrm{ml} / \mathrm{min} / 1.73 \mathrm{~m}^{2}$ at baseline, 7 -year renal survival was $88 \%$. Almost all patients were treated with an angiotensin receptor blocker or an angiotensin-converting-enzyme antagonist, in contrast to earlier epidemiologic studies, in which use of these agents was inconsistent.

In a pooled analysis of IMN studies, Hogan et al. ${ }^{14}$ reported that the probability of renal survival (that is, of not progressing to ESRD and not succumbing to death from kidney disease or from cardiovascular events related to the nephrotic syndrome) was $86 \%$ at 5 years, $65 \%$ at 10 years and $59 \%$ at 15 years. Even in patients with IMN who do not progress to renal failure, complications related to the nephrotic syndrome can lead to considerable morbidity and mortality. Individuals with the nephrotic syndrome have an increased risk of thromboembolic complications ${ }^{16}$ and experience accelerated cardiovascular disease. ${ }^{17}$

In view of the highly variable clinical course of patients with IMN, investigators have sought to identify
Kidney Disease

Section, National Institute of Diabetes and Digestive and Kidney Diseases, National Institutes of Health, Bethesda, MD, USA (M. Waldman,

H. A. Austin III).

Correspondence: M. Waldman, National Institutes of Health, 10 Center Drive, Clinical Research Center 5-2551, Bethesda, MD 20892, USA waldmanm@ niddk.nih.gov 


\section{Key points}

- Patients with idiopathic membranous nephropathy (IMN) who have a low risk of progression to end-stage renal disease are not usually treated with immunosuppressants

- The criteria for immunosuppressive treatment in patients with the nephrotic syndrome who have stable, preserved renal function are debated

- For patients with IMN who are at medium or high risk of disease progression, the most extensively studied immunosuppressive regimens comprise ciclosporin or cytotoxic agents, in combination with steroids

- Relapses of the nephrotic syndrome after cessation of treatment are a common problem in IMN

- Favorable experience of the use of rituximab in IMN is growing, but this agent is still considered an experimental therapy at present

- Adrenocorticotropic hormone and mycophenolate mofetil might have a role in IMN, but evidence is still too limited to make formal recommendations regarding the routine use of these treatments predictors that can identify high-risk patients for whom the hazards of immunosuppressive drug therapies are justified. Several clinical and biochemical parameters at presentation have been associated with poor outcomes. These include advanced age, male gender, high degrees of proteinuria, reduced GFR, severe glomerulosclerosis and tubulointerstitial changes on renal biopsy, as well as elevated levels of certain urinary proteins (urinary IgG, $\alpha_{1}$ microglobulin and $\beta_{2}$ microglobulin). ${ }^{18,19}$ More information is needed to fully evaluate the prognostic value of these and other urinary markers in patients with IMN.

Cattran, Pei and colleagues ${ }^{4,20,21}$ have derived a robust model that incorporates clinical observations that are acquired over time to predict the renal outcome of IMN. Patients with normal renal function and proteinuria of $<4 \mathrm{~g}$ per day during a 6 -month observation period are classified as low-risk ( $<5 \%$ risk of renal function deterioration during the next 5 years) and are not usually treated with immunosuppressive regimens. Patients with stable, normal renal function and persistent moderate nephrotic proteinuria ( $>4$ g per day but $<8$ g per day) during the 6-month observation period are at medium risk of progression. Individuals who have declining renal function or persistent high-grade proteinuria ( $>8 \mathrm{~g}$ per day, regardless of the level of renal function), during the 6-month period are at the highest risk of a poor renal outcome.

\section{When to treat}

Opinions differ regarding how long medium-risk and high-risk patients should be observed before they are offered immunosuppressive treatment. Patients with impaired or declining renal function or serious complications of the nephrotic syndrome are usually treated without delay. Other patients with the nephrotic syndrome tend to be observed for variable periods of time whilst receiving conservative treatments that typically include angiotensin receptor blockers or angiotensinconverting-enzyme antagonists, and statins. One treatment algorithm proposes immunosuppression for patients who have had the nephrotic syndrome for 6 or more months despite conservative treatment, in view of the risk of renal function deterioration. ${ }^{4}$

Other researchers propose a more restrictive policy whereby treatment is postponed until renal function declines, on the basis of evidence that therapeutic efficacy is not sacrificed by the delay., ${ }^{62,23}$ This point is illustrated by the results of a small, randomized, controlled trial from The Netherlands, in which 26 patients were randomized either to immediate treatment with cyclophosphamide plus steroids for 12 months or to delayed treatment with the same regimen upon detection of declining renal function (defined as an increase in serum creatinine level of $\geq 25 \%$ to $\geq 135 \mu \mathrm{mol} / \mathrm{l}) .{ }^{24}$ At baseline, patients had normal renal function, mean proteinuria of $12-14$ g per day, and were considered to be at high risk of progression to ESRD in view of their elevated urinary levels of $\beta_{2}$ microglobulin and IgG. Overall, the cumulative incidence of remissions was comparable ( $>90 \%$ ) between the two groups, but immediate treatment led to more-rapid remission. At final follow-up (mean 70 months), neither renal function nor proteinuria differed between the patients who had received immediate treatment and those who had undergone delayed treatment. Although these results are reassuring, whether such a delay has detrimental effects on long-term renal survival remains to be determined. Prolonged follow-up of large treatment groups will be required to evaluate the possible equivalence of immediate and delayed treatment of IMN.

\section{How to treat}

Investigators have explored a range of immunosuppressive regimens for patients with IMN in an effort to optimize the balance between efficacy and toxic effects.

\section{Corticosteroids}

Controlled trials have not demonstrated a consistent, sustained benefit of corticosteroid monotherapy in the treatment of membranous nephropathy. ${ }^{7,9,10,25}$ These findings are supported by two meta-analyses, which showed that corticosteroids did not improve the likelihood of remission or reduce the risk of ESRD or death compared with symptomatic therapy. ${ }^{14,26}$ Steroids are often given in conjunction with other immunosuppressants, particularly alkylating agents.

\section{Alkylating agents}

A 6-month regimen consisting of alternating months of corticosteroids and alkylating agents has both shortterm and long-term beneficial effects on proteinuria and renal survival. ${ }^{13,27-31}$ Ponticelli and colleagues ${ }^{13}$ found that this regimen increased remission rates at the final follow-up visit from $36 \%$ in untreated patients to $76 \%$, and improved 10 -year renal survival from $60 \%$ to $92 \%$. Substitution of cyclophosphamide for chlorambucil provides similar efficacy with an improved adverse effect profile. ${ }^{32}$ 
Table 1 | Selected RCTs of cytotoxic drugs in patients with IMN at moderate risk of progression ${ }^{\text {a }}$

\begin{tabular}{|c|c|c|c|c|c|c|c|}
\hline $\begin{array}{l}\text { Study } \\
\text { and year }\end{array}$ & $n$ & Treatment regimens & Follow-up & $\begin{array}{l}\text { CR rate } \\
(n)\end{array}$ & $\begin{array}{l}\mathrm{PR} \text { rate } \\
(n)\end{array}$ & $\begin{array}{l}\text { Relapse } \\
\text { rate }(n)\end{array}$ & Comments \\
\hline \multirow[t]{2}{*}{$\begin{array}{l}\text { Ponticelli } \\
\text { et al. } \\
(1995)^{13,27,28}\end{array}$} & 42 & $\begin{array}{l}\text { Months } 1,3,5 \text { : intravenous } \\
\text { methylprednisolone } 1 \mathrm{~g} \text { per day for } 3 \text { days } \\
\text { followed by oral prednisone } 0.5 \mathrm{mg} / \mathrm{kg} \text { per } \\
\text { day for } 27 \text { days; months } 2,4,6 \text { : } \\
\text { chlorambucil } 0.2 \mathrm{mg} / \mathrm{kg} \text { per day }\end{array}$ & $\begin{array}{l}\text { Up to } \\
10 \text { years }\end{array}$ & $\begin{array}{l}52 \% \\
(22 / 42)^{c}\end{array}$ & $\begin{array}{l}24 \% \\
(10 / 42)^{c}\end{array}$ & $\begin{array}{l}24 \% \\
(8 / 34)^{d}\end{array}$ & \multirow{2}{*}{$\begin{array}{l}\text { Treatment with chlorambucil and steroids } \\
\text { significantly increased } 10 \text {-year } \\
\text { dialysis-free survival }(0.92 \text { vs } 0.60 \text {; } \\
P=0.0038 \text { ) and the likelihood of } \\
\text { remission compared with symptomatic } \\
\text { treatment. Adverse events required drug } \\
\text { discontinuation in } 10 \% \text { of chlorambuci- } \\
\text { treated patients }\end{array}$} \\
\hline & 39 & $\begin{array}{l}\text { Symptomatic treatment (no } \\
\text { immunosuppression) }\end{array}$ & & $\begin{array}{l}5 \% \\
(2 / 39)^{c}\end{array}$ & $\begin{array}{l}31 \% \\
(12 / 39)^{c}\end{array}$ & $\begin{array}{l}31 \% \\
(4 / 13)^{d}\end{array}$ & \\
\hline \multirow[t]{2}{*}{$\begin{array}{l}\text { Ponticelli } \\
\text { et al. } \\
(1998)^{32}\end{array}$} & 44 & $\begin{array}{l}\text { Months } 1,3,5 \text { : intravenous } \\
\text { methylprednisolone } 1 \mathrm{~g} \text { per day for } 3 \text { days } \\
\text { followed by oral prednisolone } 0.4 \mathrm{mg} / \mathrm{kg} \text { per } \\
\text { day for } 27 \text { days; months } 2,4,6 \text { : } \\
\text { chlorambucil } 0.2 \mathrm{mg} / \mathrm{kg} \text { per day }\end{array}$ & $\begin{array}{l}\text { Median } \\
36 \text { months }\end{array}$ & $\begin{array}{l}27 \% \\
(12 / 44)^{\mathrm{e}}\end{array}$ & $\begin{array}{l}55 \% \\
(24 / 44)^{\mathrm{e}}\end{array}$ & $\begin{array}{l}31 \% \\
(11 / 36)^{\mathrm{e}}\end{array}$ & \multirow[t]{2}{*}{$\begin{array}{l}\text { No significant difference in number of } \\
\text { remissions between chlorambucil and } \\
\text { cyclophosphamide groups. Treatments } \\
\text { also led to similar improvements in renal } \\
\text { function. Chlorambucil was associated } \\
\text { with more adverse events than } \\
\text { cyclophosphamide }\end{array}$} \\
\hline & 43 & $\begin{array}{l}\text { Months } 1,3,5 \text { : intravenous } \\
\text { methylprednisolone } 1 \mathrm{~g} \text { per day for } 3 \text { days } \\
\text { followed by oral prednisolone } 0.4 \mathrm{mg} / \mathrm{kg} \text { per } \\
\text { day for } 27 \text { days; months } 2,4,6: \text { oral } \\
\text { cyclophosphamide } 2.5 \mathrm{mg} / \mathrm{kg} \text { per day }\end{array}$ & $\begin{array}{l}\text { Median } \\
42 \text { months }\end{array}$ & $\begin{array}{l}37 \% \\
(16 / 43)^{\mathrm{e}}\end{array}$ & $\begin{array}{l}56 \% \\
(24 / 43)^{\mathrm{e}}\end{array}$ & $\begin{array}{l}25 \% \\
(10 / 40)^{\mathrm{e}}\end{array}$ & \\
\hline \multirow[t]{2}{*}{$\begin{array}{l}\text { Jha et al. } \\
(2007)^{29}\end{array}$} & 47 & $\begin{array}{l}\text { Months } 1,3,5 \text { : intravenous } \\
\text { methylprednisolone } 1 \mathrm{~g} \text { per day for } 3 \text { days, } \\
\text { followed by oral prednisolone } 0.5 \mathrm{mg} / \mathrm{kg} \text { per } \\
\text { day for } 27 \text { days; months } 2,4,6 \text { : oral } \\
\text { cyclophosphamide } 2 \mathrm{mg} / \mathrm{kg} \text { per day for } \\
30 \text { days }^{b}\end{array}$ & $\begin{array}{l}\text { Median } \\
11 \text { years }\end{array}$ & $\begin{array}{l}32 \% \\
(15 / 47)\end{array}$ & $\begin{array}{l}40 \% \\
(19 / 47)\end{array}$ & $\begin{array}{l}24 \% \\
(8 / 34)\end{array}$ & \multirow[t]{2}{*}{$\begin{array}{l}\text { Patients treated with steroids and } \\
\text { cyclophosphamide had a reduced risk of } \\
\text { reaching the composite end point (death, } \\
\text { dialysis or doubling of serum creatinine) } \\
\text { or progressing to end-stage renal disease }\end{array}$} \\
\hline & 46 & No immunosuppression ${ }^{b}$ & & $\begin{array}{l}11 \% \\
(5 / 46)\end{array}$ & $\begin{array}{l}24 \% \\
(11 / 46)\end{array}$ & $\begin{array}{l}25 \% \\
(4 / 16)\end{array}$ & \\
\hline
\end{tabular}

aModerate risk is defined as the presence of nephrotic syndrome and preserved renal function. ${ }^{\mathrm{b} A n g i o t e n s i n-c o n v e r t i n g-e n z y m e ~ i n h i b i t o r s ~ a n d ~ a n g i o t e n s i n ~ r e c e p t o r ~ b l o c k e r s ~ w e r e ~ w i t h h e l d ~ f o r ~ a t ~}$ least 1 year. ${ }^{\mathrm{C}}$ Data at the last follow-up visit. ${ }^{13}$ dData reported in $1989 .{ }^{27}$ eResults are based on the 87 of 95 patients who completed 1 year of follow-up. Abbreviations: CR, complete remission; IMN, idiopathic membranous nephropathy; PR, partial remission; RCT, randomized, controlled trial.

The long-term outcomes of a randomized, controlled trial from India are consistent with the above data. Jha and colleagues ${ }^{29}$ randomized patients to receive either supportive treatment or 6 months of alternating prednisolone and oral cyclophosphamide therapy. Crossover to the immunosuppressive treatment arm was permitted 24 months after randomization. Compared with patients randomized to receive supportive therapy, those randomized to undergo immunosuppressive treatment had higher rates of remission (72\% versus 35\%; $P<0.0001)$, higher 10 -year dialysis-free survival (89\% versus $65 \%$; $P=0.016)$ and a higher likelihood of survival free of dialysis or doubling of serum creatinine level (79\% versus 44\%; $P=0.0006)$. Relapse occurred in approximately one-quarter of patients in both groups, on average 6 months after remission was achieved. Notably, remission rates were lower among patients who switched to immunosuppression as rescue therapy $(47 \%)$ than among those who were initially randomized to such treatment (72\%). This finding contrasts with the results of the Dutch study, which indicated that a delay in therapy did not lead to differences in efficacy. ${ }^{24}$

The aforementioned trials included predominantly medium-risk patients with preserved renal function (Table 1). Several randomized, controlled trials (Table 2) and small, prospective studies have evaluated cytotoxic drug regimens in the high-risk population of patients with reduced or declining GFR..$^{22,23,30,33-37}$ A 2004 study from The Netherlands compared renal outcomes between 65 high-risk patients who were treated for 1 year with oral cyclophosphamide plus steroids, and 24 historical matched control patients. ${ }^{23}$ The control patients received either no immunosuppressive treatment or treatments that have subsequently proven to be ineffective (prednisone monotherapy or intravenous cyclophosphamide, or both). At baseline, patients in both groups had renal insufficiency (serum creatinine level $>135 \mu \mathrm{mol} / \mathrm{l}$, creatinine clearance $<70 \mathrm{ml} / \mathrm{min}$ or rise in serum creatinine $>50 \%$ ) and high-grade proteinuria. Approximately $25 \%$ of patients treated with the extended regimen of oral cyclophosphamide experienced complete remission and another $60 \%$ achieved partial remission. The cumulative incidence of relapse 5 years after remission in the cyclophosphamide group was almost $30 \%$. Nevertheless, immunosuppressive therapy markedly lessened the decline in renal function: more than $90 \%$ of patients showed a reduction in serum creatinine level of at least $10 \%$ during the first year of treatment. Renal survival at 5 years was significantly higher in the oral cyclophosphamide arm than in the historic controls ( $86 \%$ versus $32 \% ; P<0.001$ ). Infection occurred in $26 \%$ of patients who received oral cyclophosphamide.

Despite the favorable results of alkylating agents in IMN, many physicians are reluctant to use these drugs, 
Table 2 | Selected immunosuppressive treatment comparisons in patients with IMN at high risk of progression

\begin{tabular}{|c|c|c|c|c|}
\hline $\begin{array}{l}\text { Study, year } \\
\text { and design }\end{array}$ & $n$ & Treatment regimens & $\begin{array}{l}\text { Follow-up } \\
\text { (months) }\end{array}$ & Comments \\
\hline $\begin{array}{l}\text { Falk et al. } \\
(1992) ; 33 \\
\text { RCT }\end{array}$ & 26 & $\begin{array}{l}\text { Intravenous monthly pulse cyclophosphamide } 0.5-1.0 \mathrm{~g} / \mathrm{m}^{2} \text { for } 6 \text { months } \\
\text { plus pulse methylprednisolone and oral prednisone } 1 \mathrm{mg} / \mathrm{kg} \text { for } 2 \text { months, } \\
\text { then tapered } \\
\text { Alternate-day oral prednisone }(2 \mathrm{mg} / \mathrm{kg}) \text { for } 2 \text { months, then tapered }\end{array}$ & Mean 29 & $\begin{array}{l}\text { Pulse intravenous cyclophosphamide plus } \\
\text { corticosteroids does not improve renal } \\
\text { function or renal survival compared with } \\
\text { corticosteroids alone }\end{array}$ \\
\hline $\begin{array}{l}\text { Reichert } \\
\text { et al. } \\
\text { (1994); }{ }^{30} \\
\text { RCT }\end{array}$ & 18 & $\begin{array}{l}\text { Months } 2,4,6 \text { : oral chlorambucil } 0.15 \mathrm{mg} / \mathrm{kg} \text { per day; months } 1,3,5 \text { : pulse } \\
\text { methylprednisolone } 1 \mathrm{~g} \text { per day for } 3 \text { days, then oral prednisone } 0.5 \mathrm{mg} / \mathrm{kg} \\
\text { per day for } 27 \text { days } \\
\text { Monthly intravenous pulse cyclophosphamide } 750 \mathrm{mg} / \mathrm{m}^{2} \text { for } 6 \text { months plus } \\
\text { intravenous methylprednisolone as three } 1 \mathrm{~g} \text { doses in months } 1,3 \text { and } 5\end{array}$ & Median 15 & $\begin{array}{l}\text { Oral chlorambucil, but not intermittent pulse } \\
\text { cyclophosphamide, improves renal function }\end{array}$ \\
\hline $\begin{array}{l}\text { Branten et al. } \\
(1998)^{22} \\
\text { partially } \\
\text { randomized }\end{array}$ & 32 & $\begin{array}{l}\text { Oral cyclophosphamide } 1.5-2 \mathrm{mg} / \mathrm{kg} \text { per day for } 12 \text { months, plus steroids } \\
\text { (oral prednisone in all cases; } 10 \text { patients also received pulse } \\
\text { methylprednisolone } 1 \mathrm{~g} \text { per day for } 3 \text { days at the start of months } 1,3 \text { and 5) } \\
\text { Months } 2,4,6 \text { : oral chlorambucil } 0.15 \mathrm{mg} / \mathrm{kg} \text { per day; months } 1,3,5 \text { : pulse } \\
\text { methylprednisolone } 1 \mathrm{~g} \text { per day for } 3 \text { days, then oral prednisone } 0.5 \mathrm{mg} / \mathrm{kg} \\
\text { per day for } 27 \text { days }\end{array}$ & $\begin{array}{l}\text { Median } 26 \\
\text { Median } 38\end{array}$ & $\begin{array}{l}\text { Improvement or stabilization of renal } \\
\text { function and remission of proteinuria more } \\
\text { frequent with cyclophosphamide regimen } \\
\text { than with chlorambucil regimen. } \\
\text { Chlorambucil was associated with more } \\
\text { adverse events than cyclophosphamide }\end{array}$ \\
\hline $\begin{array}{l}\text { Cattran et al. } \\
\text { (1995); }{ }^{41} \\
\text { RCT }\end{array}$ & 17 & $\begin{array}{l}\text { Oral ciclosporin for } 12 \text { months (initial dose } 3.5 \mathrm{mg} / \mathrm{kg} \text { per day) } \\
\text { Placebo }\end{array}$ & Mean 48 & $\begin{array}{l}\text { Ciclosporin was associated with slowing in } \\
\text { rate of decline in renal function compared } \\
\text { with placebo }\end{array}$ \\
\hline
\end{tabular}

Abbreviations: IMN, idiopathic membranous nephropathy; RCT, randomized, controlled trial.

because of concerns that patients, particularly those with reduced GFR, are at increased risk of infection and myelosuppression. Cancer risk is of particular concern when alkylating agents are used for an extended period. An analysis of patients with Wegener granulomatosis reported that cumulative doses of more than $36 \mathrm{~g}$ of cyclophosphamide (equivalent to $100 \mathrm{mg}$ daily for one year) were associated with a 9.5-fold increased risk of bladder cancer. ${ }^{38}$ Extended courses of cyclophosphamide have also been associated with an increased risk of lymphoproliferative disorders. ${ }^{38,39}$

Relapses occur in $25-30 \%$ of patients within 5 years of discontinuation of therapy with alkylating agents. This rate of relapse is lower than that observed after discontinuation of ciclosporin (as discussed below); however, it is still disconcerting since relapses generally necessitate increased immunosuppression, with its attendant adverse effects. ${ }^{13,23,29,32}$ Finally, some clinicians doubt the efficacy of alkylating agents in IMN, because a meta-analysis failed to show that these drugs have a beneficial effect on overall mortality or risk of ESRD despite inducing remission of proteinuria. ${ }^{26}$ This finding is interesting and curious as it seems to belie the notion that reduction of proteinuria is a surrogate end point for reduction of ESRD risk. However, the average durations of follow-up in most of the trials included in the meta-analysis were too short to observe an effect on the hard end point of renal survival. Furthermore, meta-analyses do not take into account subtle variations in study design that can affect outcomes.

\section{Calcineurin inhibitors}

\section{Ciclosporin}

Ciclosporin reduces proteinuria and the rate of decline in renal function in patients with IMN. These effects have been demonstrated in patients with preserved renal function, in those with declining or impaired renal function and also in patients resistant to other immunosuppressants, ${ }^{40-50}$ as summarized elsewhere (Tables 2 and 3). ${ }^{51,52}$ Several issues deserve to be highlighted. In patients with preserved renal function (Table 3), treatment with ciclosporin for 26 weeks led to more total remissions and complete remissions than placebo. However, high rates of relapse occurred after drug discontinuation: almost $50 \%$ of patients who had achieved remission relapsed within 1 year of ciclosporin withdrawal (the majority within 6 months). ${ }^{40}$ In high-risk patients with declining renal function (Table 2), 12 months of ciclosporin treatment led to a $50 \%$ reduction in proteinuria in half of the patients, and slowed the rate of renal deterioration compared with placebo. ${ }^{41}$

Notably, no prospective, randomized, head-tohead comparisons of ciclosporin and alkylating agents have been conducted in IMN. A retrospective study by Goumenos et al. ${ }^{48}$ attempted to address this issue by comparing the outcomes of patients who were treated with the 6-month Ponticelli protocol (steroids plus chlorambucil or cyclophosphamide; $n=31$ ) with the outcomes of patients who received ciclosporin (for 2 years) plus steroids $(n=46)$. The use of the two different therapeutic regimens reflects the change in institutional treatment preference over a 10 -year period. Baseline characteristics of the groups were similar. More remissions occurred among the ciclosporin-treated patients than among those treated with the cytotoxic regimen (85\% versus 55\%; $P=0.004$ ); however, relapses tended to occur more often after ciclosporin treatment than after cytotoxic therapy (41\% versus $29 \% ; P=$ nonsignificant). The design and retrospective nature of the study precludes the drawing of 
Table 3 | Selected RCTs of calcineurin inhibitors in patients with IMN at moderate risk of progression ${ }^{\text {a }}$

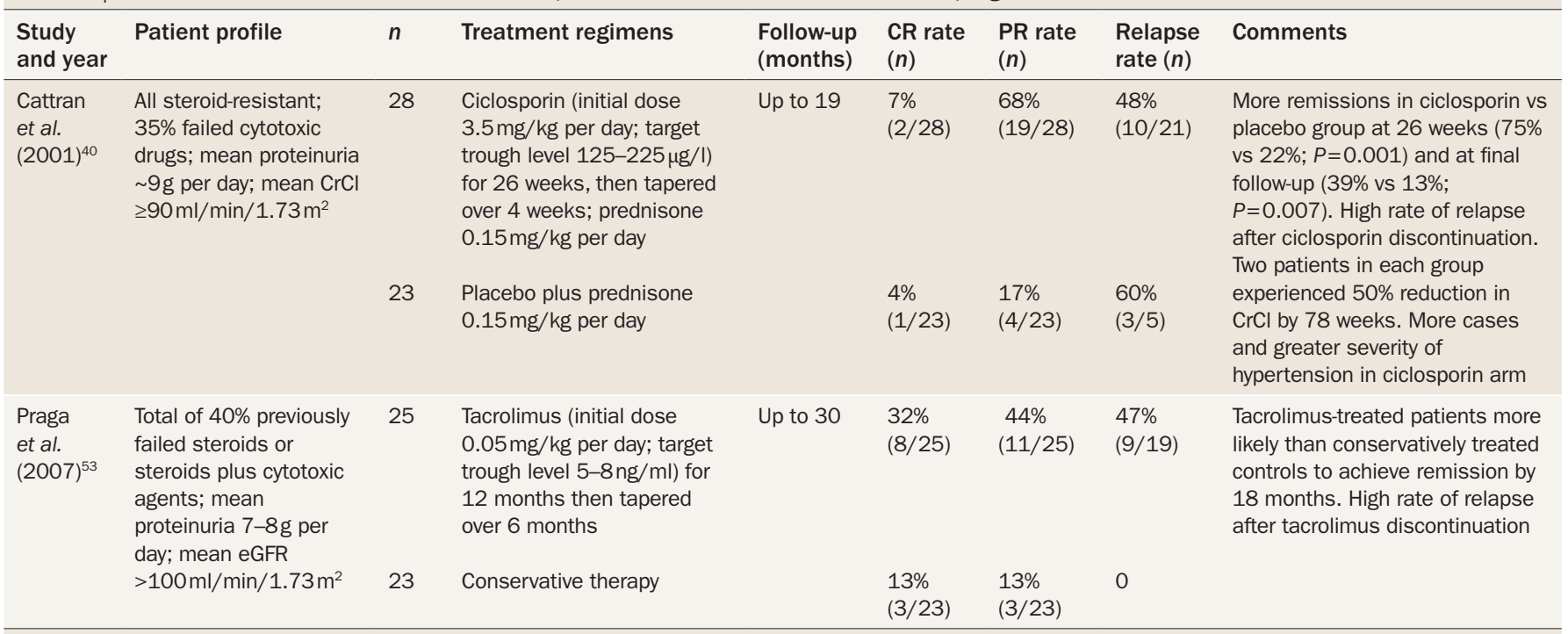

aModerate risk is defined as the presence of nephrotic syndrome and preserved renal function. Abbreviations: CR, complete remission; CrCl, creatinine clearance; eGFR, estimated glomerular filtration rate; IMN, idiopathic membranous nephropathy; PR, partial remission; RCT, randomized, controlled trial.

definitive conclusions regarding the comparative effects of ciclosporin and alkylating agents in IMN.

The optimal dose and duration of treatment with ciclosporin has been difficult to establish. On the basis of the available data, extended therapy seems to enhance the likelihood of remission. In one analysis, the majority of complete remissions occurred after at least 6 months of therapy, and the number increased as treatment continued for more than 12 months. ${ }^{43}$ Thereafter, the combination of low-dose ciclosporin $(1.4-1.5 \mathrm{mg} / \mathrm{kg}$ per day; trough levels $>100 \mathrm{ng} / \mathrm{ml})$ and prednisolone $(0.1 \mathrm{mg} / \mathrm{kg}$ per day) might be more beneficial than ciclosporin monotherapy for maintaining remission and preventing relapse. ${ }^{50}$ Guidelines for the use of ciclosporin in IMN have been published on the basis of recommendations from an international conference. ${ }^{52}$

\section{Tacrolimus}

Several investigators have evaluated whether tacrolimus could provide similar efficacy to ciclosporin in IMN. ${ }^{53-55}$ Tacrolimus is considered to be more potent than ciclosporin, has a more favorable cardiovascular risk profile and leads to better long-term renal function after renal transplantation. ${ }^{56-58}$ In a multicenter study in Spain, Praga et al. ${ }^{53}$ randomized 48 medium-risk patients to receive either conservative therapy (controls) or tacrolimus monotherapy for 18 months (Table 3). Patients had preserved renal function and persistent nephrotic syndrome of more than 9 months' duration despite receiving maximal doses of angiotensin-converting-enzyme inhibitors or angiotensin receptor blockers. After 18 months of treatment, the tacrolimus group had a higher percentage of remissions than the control group $(76 \%$ versus $26 \% ; P=0.003$ ). The overall remission rate achieved with tacrolimus is similar to that reported with ciclosporin but the rate of complete remissions is greater with tacrolimus. This difference might be, in part, related to the long duration of therapy used in this study (18 months, compared with 26 weeks in the study of ciclosporin by Cattran ${ }^{40}$ ). Nevertheless, as with ciclosporin, relapses were frequent, occurring in $47 \%$ of treated patients within an average of 4 months following discontinuation of tacrolimus. ${ }^{53}$ Thus, at final follow-up (30 months), the numbers of remissions were not markedly different between the treatment arms.

Aside from the high incidence of relapse after drug discontinuation (up to $48 \%$ ), the nephrotoxic effects of calcineurin inhibitors are of concern, particularly if long-term treatment is required as a result of relapses. Managing the use of these agents in patients with reduced GFR can be difficult. In light of this issue, Ponticelli and Villa ${ }^{59}$ recommend alternative agents in patients with impaired renal function (creatinine clearance $<60 \mathrm{ml} / \mathrm{min}$ ), severe hypertension or severe interstitial fibrosis and tubular atrophy. Finally, the extent to which calcineurin inhibitors affect the underlying immune process rather than merely modifying disease expression is unclear. ${ }^{49}$

In view of the broad range of toxic effects and the high rates of relapse associated with the use of steroids, alkylating agents and calcineurin inhibitors, alternative treatments have been investigated.

\section{Antimetabolites}

\section{Mycophenolate mofetil}

Clinical efficacy studies of mycophenolate mofetil (MMF) in IMN have produced mixed results (Table 4). ${ }^{60-68} \mathrm{In}$ a multicenter study in China, Chan et al. ${ }^{66}$ randomized 20 newly diagnosed patients with persistent proteinuria $\geq 3$ g per day to undergo 6 months of treatment with 
Table 4 | Selected studies of MMF in patients with IMN

\begin{tabular}{|c|c|c|c|c|c|c|c|c|}
\hline $\begin{array}{l}\text { Study, year } \\
\text { and design }\end{array}$ & Patient profile & $n$ & Treatment regimens & $\begin{array}{l}\text { Follow-up } \\
\text { (months) }\end{array}$ & $\begin{array}{l}\mathrm{CR} \\
\text { rate }(n)\end{array}$ & $\begin{array}{l}\text { PR rate } \\
(n)\end{array}$ & $\begin{array}{l}\text { Relapse } \\
\text { rate }(n)\end{array}$ & Comments \\
\hline $\begin{array}{l}\text { Chan et al. } \\
\text { (2007);66 } \\
\text { RCT }\end{array}$ & $\begin{array}{l}\text { Treatment-naïv; } \\
\text { proteinuria } \geq 3 g \\
\text { per day and } \\
\text { preserved renal } \\
\text { function }\end{array}$ & 11 & $\begin{array}{l}\text { MMF } 2 \mathrm{~g} \text { per day for } 6 \text { months and } \\
\text { prednisolone } 0.8 \mathrm{mg} / \mathrm{kg} \text { per day, } \\
\text { then tapered off by } \sim 6 \text { months } \\
\text { Alternating treatment with steroids } \\
\text { (months } 1,3,5 \text { : intravenous } \\
\text { methylprednisolone } 1 \mathrm{~g} \text { per day for } \\
3 \text { days followed by oral prednisolone } \\
0.4 \mathrm{mg} / \mathrm{kg} \text { per day for } 21 \text { days, then } \\
0.2 \mathrm{mg} / \mathrm{kg} \text { per day for } 6 \text { days) and } \\
\text { oral chlorambucil }(0.2 \mathrm{mg} / \mathrm{kg} \text { per day } \\
\text { during months } 2,4,6)\end{array}$ & Up to 15 & $\begin{array}{l}27.2 \% \\
(3 / 11)\end{array}$ & $\begin{array}{l}36.4 \% \\
(4 / 11)\end{array}$ & $29 \%(2 / 7)$ & $\begin{array}{l}\text { MMF regimen had comparable } \\
\text { efficacy to chlorambucil } \\
\text { regimen: similar rate of total } \\
\text { remissions ( } 64 \% \text { vs } 67 \% \text { ) and } \\
\text { overall proteinuria reduction } \\
\text { ( } 4.9 \mathrm{~g} \text { per day to } 1.5 \mathrm{~g} \text { per day } \\
\text { vs } 5.8 \mathrm{~g} \text { per day to } 1 \mathrm{~g} \text { per day) }\end{array}$ \\
\hline $\begin{array}{l}\text { Branten } \\
\text { et al. } \\
(2007) ; 67 \\
\text { matched } \\
\text { historical } \\
\text { comparison }\end{array}$ & $\begin{array}{l}\text { High risk; } \\
\text { median } \\
\text { proteinuria } \\
>8 \mathrm{~g} / \mathrm{g} \\
\text { creatinine; } \\
\text { median eGFR } \\
40 \mathrm{ml} / \\
\mathrm{min} / 1.73 \mathrm{~m}^{2}\end{array}$ & 32 & $\begin{array}{l}\text { MMF } 2 \mathrm{~g} \text { per day for } 12 \text { months plus } \\
\text { steroids (months } 1,3,5 \text { : } \\
\text { intravenous methylprednisolone } 1 \mathrm{~g} \\
\text { per day for } 3 \text { days; oral prednisone } \\
0.5 \mathrm{mg} / \mathrm{kg} \text { on alternate days for } \\
6 \text { months, followed by tapering) } \\
\\
\text { Daily oral cyclophosphamide } \\
1.5 \mathrm{mg} / \mathrm{kg} \text { per day for } 12 \text { months } \\
\text { plus similar steroid regimen as MMF } \\
\text { group }\end{array}$ & Median 23 & NR & $\begin{array}{l}66 \% \\
(21 / 32)\end{array}$ & $\begin{array}{l}57 \% \\
(12 / 21) \text { at } \\
2 \text { years }\end{array}$ & $\begin{array}{l}\text { At last follow-up, patients in } \\
\text { MMF group were less likely to } \\
\text { be in remission than historic } \\
\text { controls treated with } \\
\text { cyclophosphamide }(P=0.021) \text {. } \\
\text { Similar frequency of infections } \\
\text { in the two groups. Nine } \\
\text { patients in MMF group and two } \\
\text { in cyclophosphamide group } \\
\text { were treated after relapse with } \\
\text { cyclophosphamide }\end{array}$ \\
\hline $\begin{array}{l}\text { Dussol et al. } \\
\text { (2008);68 } \\
\text { RCT }\end{array}$ & $\begin{array}{l}\text { Treatment-naïve; } \\
\text { nephrotic } \\
\text { syndrome; } \\
\text { preserved renal } \\
\text { function }\end{array}$ & 17 & $\begin{array}{l}\text { MMF } 2 g \text { per day plus conservative } \\
\text { treatment for } 12 \text { months } \\
\text { Conservative treatment for } \\
12 \text { months }\end{array}$ & Up to 12 & $\begin{array}{l}5 \% \\
(1 / 19) \\
12 \% \\
(2 / 17)\end{array}$ & $\begin{array}{l}32 \% \\
(6 / 19) \\
\\
29 \% \\
(5 / 17)\end{array}$ & NR & $\begin{array}{l}\text { No major difference in } \\
\text { probability of CR or PR } \\
\text { between groups. Kidney } \\
\text { function was stable and not } \\
\text { different between groups }\end{array}$ \\
\hline
\end{tabular}

Abbreviations: CR, complete remission; eGFR, estimated glomerular filtration rate; IMN, idiopathic membranous nephropathy; MMF, mycophenolate mofetil; NR, not reported; PR, partial remission; RCT, randomized, controlled trial.

either MMF plus prednisolone or with a regimen of chlorambucil alternating monthly with corticosteroids. The groups achieved similar remission rates $(\sim 65 \%)$ and experienced few relapses, which suggests that MMF in conjunction with steroids has similar efficacy to a modified Ponticelli regimen. However, the study was not powered to demonstrate equivalency or noninferiority, follow-up was limited and only patients with a favorable risk profile were enrolled. Furthermore, the study included only Asian patients; therefore, the favorable results might not be generalizable to other patient populations. Studies of other primary glomerulopathies indicate that ethnicity can influence both prognosis and responsiveness to certain immunosuppressants. ${ }^{69-71}$ In support of this concept, a retrospective analysis from Japan suggested that a 4-week course of steroids in patients with IMN led to improved renal survival, ${ }^{72}$ which contrasts with the absence of benefit of steroid monotherapy in other ethnic populations. ${ }^{7,9,10,25}$

An open-label trial in The Netherlands evaluated the efficacy of MMF in patients considered to be at high risk of disease progression. ${ }^{67}$ The outcomes of 32 patients treated for 1 year with MMF (2 g per day) and steroids were compared with those of historic matched controls treated with oral cyclophosphamide plus corticosteroids for 1 year. Patients in both groups had reduced GFR at baseline (median approximately $40 \mathrm{ml} / \mathrm{min}$ ) and median proteinuria was $>8 \mathrm{~g} / \mathrm{g}$ creatinine. The two groups achieved similar remission rates (approximately $70 \%)$. However, the risk of post-treatment relapse was considerably higher in the MMF group such that by the end of follow-up (median 23 months), patients in the MMF arm were less likely to be in remission than those in the cyclophosphamide control arm (44\% versus $75 \% ; P=0.02)$. Nevertheless, both treatments resulted in stabilization or improvement of renal function in the majority of patients, and infections and hospitalization occurred at a similar frequency in the two groups. Although the investigators concluded that MMF did not seem to be as effective as nor any better tolerated than cyclophosphamide, this study does suggest that a prolonged course of MMF might be of benefit even in patients with unfavorable baseline characteristics.

In contrast to the above-mentioned studies, responses to MMF in a multicenter randomized, controlled trial in France were poor. Dussol et al. ${ }^{68}$ randomized 36 patients to conservative treatment alone (angiotensin-convertingenzyme inhibitors, statins, low-salt and low-protein diet and loop diuretics as needed) or to MMF ( $2 \mathrm{~g}$ per day) plus conservative measures for 12 months. Patients were treatment-naïve, recently diagnosed ( $<6$ months), and had the nephrotic syndrome and preserved renal function. At 1 year, the proportion of remissions was approximately $40 \%$ in both groups.

In summary, MMF might have a place in the treatment of IMN, but given its limited and conflicting efficacy 
Table 5 | Selected pilot trials of rituximab monotherapy in patients with IMN

\begin{tabular}{|c|c|c|c|c|c|c|c|}
\hline Study and year & $n$ & Patient profile & Treatment regimen & $\begin{array}{l}\text { Follow-up } \\
\text { (months) }\end{array}$ & CR rate & PR rate & Comments \\
\hline $\begin{array}{l}\text { Remuzzi et al. } \\
(2002)^{77} \\
\text { Ruggenenti et al. } \\
(2003)^{78}\end{array}$ & 8 & $\begin{array}{l}\text { Mean proteinuria } 8.6 \text { g per day; mean } \\
\mathrm{CrCl} 69 \mathrm{ml} / \mathrm{min} \text {; all receiving ACE } \\
\text { inhibitors }\end{array}$ & $\begin{array}{l}\text { Four doses of } 375 \mathrm{mg} / \mathrm{m}^{2} \text { per } \\
\text { week }\end{array}$ & 12 & $\begin{array}{l}25 \% \\
(2 / 8)^{\mathrm{a}}\end{array}$ & $\begin{array}{l}50 \% \\
(4 / 8)^{b}\end{array}$ & $\begin{array}{l}\text { Mean reduction } \\
\text { in proteinuria was } \\
66 \%\end{array}$ \\
\hline $\begin{array}{l}\text { Fervenza et al. } \\
(2008)^{80}\end{array}$ & 15 & $\begin{array}{l}\text { Mean proteinuria } 13 g \text { per day; mean } \\
\mathrm{CrCl} 85 \mathrm{ml} / \mathrm{min} \text {; all receiving ACE } \\
\text { inhibitors or ARBs for at least } \\
4 \text { months }\end{array}$ & $\begin{array}{l}\text { Two } 1 \mathrm{~g} \text { doses (on days } 1 \text { and } \\
15 \text { ); repeated at } 6 \text { months if } \\
\text { proteinuria }>3 \text { g per day and } \\
\text { CD19+ } B \text { cells }>15 / \mu l(n=10)\end{array}$ & 12 & $\begin{array}{l}14 \% \\
(2 / 14)^{c, d}\end{array}$ & $\begin{array}{l}43 \% \\
(6 / 14)^{d, e}\end{array}$ & $\begin{array}{l}\text { Mean reduction } \\
\text { in proteinuria was } \\
48 \%\end{array}$ \\
\hline
\end{tabular}

${ }^{a} \mathrm{CR}$ was defined as proteinuria $\leq 0.5 \mathrm{~g} / 24 \mathrm{~h}$. ${ }^{\mathrm{DPR}}$ was defined as proteinuria $\leq 3.5 \mathrm{~g} / 24 \mathrm{~h}$ or $>50 \%$ reduction in proteinuria. ${ }^{\mathrm{c}} \mathrm{CR}$ was defined as proteinuria $<0.3 \mathrm{~g} / 24 \mathrm{~h}$. ${ }^{\mathrm{d}} \mathrm{Results}$ are based on the 14 patients who completed the trial. ePR was defined as proteinuria $\leq 3 \mathrm{~g} / 24 \mathrm{~h}$ and $>50 \%$ reduction in proteinuria. Abbreviations: ACE, angiotensin-converting enzyme; ARB, angiotensin receptor blocker; CR, complete remission; $\mathrm{CrCl}$, creatinine clearance; IMN, idiopathic membranous nephropathy; PR, partial remission.

data, firm recommendations regarding the use of this agent as initial therapy are difficult to make. MMF might be a reasonable option when the toxic effects of alkylating agents and high-dose steroids are of particular concern or when severe azotemia prohibits use of calcineurin inhibitors. Studies in large numbers of patients with prolonged follow-up are needed to determine the long-term effectiveness of MMF for maintenance of remission and preservation of renal function. Additional information is also needed to fully evaluate the adverse effect profile of MMF. FDA 'black box' warnings indicate that MMF is associated with pregnancy loss and congenital malformations; furthermore, MMF can increase the risk of lymphoma and infection. Cases of JC-virus-associated progressive multifocal leukoencephalopathy in patients with systemic lupus erythematosus receiving MMF have elicited concern. All these considerations must be weighed in the decision to use MMF in IMN.

\section{Azathioprine}

Before the use of MMF became widespread, azathioprine was tested as a treatment for IMN in several small studies, with mixed results. A combination of azathioprine and corticosteroids was reported to be beneficial in high-risk patients with declining renal function. ${ }^{73-75}$ Some patients experienced reduction in proteinuria and stabilization or improvement of renal function. However, these studies were case series with no control groups and the combined number of patients analyzed (29) was small. In contrast to these favorable findings, a retrospective review from Greece indicated that azathioprine had no long-term benefit in IMN. ${ }^{76}$ A total of 33 medium-risk patients with IMN who were treated with azathioprine (for a mean of 26 months) plus prednisone (for approximately 12 months) were compared with 17 patients at the same institution who received no treatment; the decision to treat was based on individual physician preference. Baseline characteristics in the two groups were similar. After 10 years of follow-up, the rates of remission in the treated and untreated groups were not substantially different (51\% versus $58 \%$ ). The risks of doubling of serum creatinine level (42\% versus 35\%) or reaching ESRD (21\% versus 18\%) were also similar.
In light of the conflicting evidence regarding the efficacy of azathioprine in IMN and the popularity of MMF, azathioprine is unlikely to be tested in future randomized trials in this setting.

\section{Rituximab}

Clinical experience with use of the anti-CD20 antibody, rituximab, in IMN is growing (Table 5). ${ }^{77-83}$ Remuzzi, Ruggenenti and colleagues ${ }^{77,78}$ in Italy administered four weekly intravenous doses of rituximab $\left(375 \mathrm{mg} / \mathrm{m}^{2}\right)$ to eight high-risk patients who remained nephrotic after 6 months of angiotensin-converting-enzyme inhibitor therapy. Mean proteinuria at baseline was $8.6 \mathrm{~g}$ per day and mean creatinine clearance was $69 \mathrm{ml} / \mathrm{min}$. Mean proteinuria decreased by $51 \%$ at 3 months and by $66 \% 1$ year after treatment. ${ }^{78}$ These investigators subsequently treated 50 consecutive medium-risk or high-risk patients with the same regimen; remission (proteinuria $<0.5$ g per day) was achieved in $20 \%$ and was associated with improvement in ultrastructural findings on repeat renal biopsies. ${ }^{84}$

In a pilot trial, Fervenza et al. ${ }^{80}$ used an intravenous rituximab regimen of $1 \mathrm{~g}$ on days 1 and 15 to treat 15 patients with IMN who had severe proteinuria (mean $13 \mathrm{~g}$ per day, range $8-24 \mathrm{~g}$ per day). Half of the patients had failed previous immunosuppressive treatments. After 6 months, 4 patients (27\%) achieved partial remission. Ten patients were treated with a second course of rituximab, because they exhibited persistent nephrotic-range proteinuria and recovery of B-cell counts. By 12 months, of the 14 patients who completed the trial, 2 (14\%) had achieved complete remission and 6 (43\%) had experienced partial remission. Overall, proteinuria was reduced by $48 \%$ from baseline to month 12 . Five patients showed no response to two full courses of rituximab; two of these individuals progressed to ESRD.

Although the effect of rituximab on CD20-expressing $\mathrm{B}$ cells is rapid, the reduction in proteinuria can occur gradually over many months. ${ }^{78,82}$ Furthermore, changes in circulating B-lymphocyte counts are not consistently associated with remission or relapse of proteinuria. Nonimmune factors might contribute to the variability in responses to rituximab. In one study, patients with 
modest tubulointerstitial injury and fibrosis-as indicated by tubulointerstitial injury scores of $<1.7$ - showed halving of baseline proteinuria within 3 months of rituximab treatment, whereas those with tubulointerstitial injury scores of $\geq 1.7$ did not experience meaningful improvements in proteinuria. ${ }^{82}$ On the other hand, Fervenza et al. did not find substantial differences in renal pathology between responders and nonresponders. ${ }^{80}$ The discordance in findings between these two studies might be related to baseline differences in the degree of tubulointerstitial disease in the study populations. In the latter trial, ${ }^{80}$ patients had more-limited tubulointerstitial disease; thus, detection of differences in response rates on the basis of this histological feature might have been difficult.

The optimal dosing and frequency of rituximab for the treatment of IMN need to be defined. The currently used regimens have been adapted from those approved for non-Hodgkin lymphoma (four weekly infusions of $375 \mathrm{mg} / \mathrm{m}^{2}$ ) and rheumatoid arthritis (two $1 \mathrm{~g}$ doses given two weeks apart), but the pharmacokinetics of rituximab might be different in patients with IMN. Highgrade non-selective proteinuria could theoretically lead to loss of rituximab in the urine and thereby decrease the drug's efficacy. ${ }^{80}$

A balanced perspective regarding the toxicity profile of rituximab is needed. Although infusion reactions (including fever, chills, pruritus and skin rash) are often mild and manageable, more severe and potentially fatal reactions have occurred (including acute respiratory distress syndrome, bronchospasm, angioedema, shock and myocardial infarction). The FDA black box warning also indicates that potentially fatal mucocutaneous reactions, such as Stevens-Johnson syndrome and toxic epidermal necrolysis, can occur following rituximab exposure. Severe infections are infrequent, occurring in only $1-2 \%$ of patients. Of great concern, rare cases of progressive multifocal leukoencephalopathy have been reported with rituximab use, particularly as part of a multidrug immunosuppressive regimen. Physicians and patients need to be aware of the presenting features of this devastating demyelinating disease of the central nervous system, which include altered mental status, visual symptoms, motor deficits and ataxia.

The preliminary results of rituximab treatment are encouraging, but much remains to be learnt before this agent can be recommended for routine use in IMN. So far, no randomized, controlled trials have been conducted to clarify the role of rituximab in the therapeutic armamentarium for IMN. Adequately powered, randomized, controlled trials with prolonged follow-up are needed to determine the long-term course of the disease following B-cell reconstitution; rates of relapse; subsequent redosing regimens; and effects on renal survival. Further studies must clarify whether rituximab should be used as monotherapy or in combination with other immunosuppressive drugs to achieve maximum antiproteinuric effect and durable remission. The preliminary results of a small, uncontrolled study in Spain suggest that the addition of rituximab to tacrolimus can induce sustained remission of the nephrotic syndrome, allowing early tacrolimus withdrawal and thereby overcoming the issue of tacrolimus dependence. ${ }^{85}$

\section{Adrenocorticotropic hormone}

Several small, uncontrolled trials have reported beneficial effects of synthetic adrenocorticotropic hormone (ACTH) in patients with IMN. .6-88 $^{8 n e}$ small, randomized, controlled trial by Ponticelli et al. ${ }^{89}$ compared treatment with ACTH for 1 year to a 6-month regimen of methylprednisolone alternating monthly with a cytotoxic agent in 32 (mostly medium-risk) patients with IMN. The probability of complete or partial remission did not differ substantially between the groups ( $87 \%$ versus $93 \%$ ), and the number of remissions, mean time to response and number of relapses were also comparable between the groups. The small size and limited follow-up of the study (mean 21 months) make it difficult to determine the true risk of relapse and the long-term effect of ACTH on kidney function. Nevertheless, the results suggest that prolonged ACTH treatment could be equivalent to the combined use of cytotoxic drugs and steroids. Adverse effects of ACTH include glucose intolerance, fluid retention, hypertension, diarrhea, bronze discoloration of the skin, dizziness and fatigue, all of which resolve after discontinuation of treatment.

Extensive studies with long follow-up are needed to confirm the preliminary data on the use of ACTH in IMN. Further investigation is also required to elucidate the mechanisms by which ACTH seems to decrease proteinuria and alter apolipoprotein metabolism. ${ }^{86}$ These effects are probably not entirely attributable to an increase in endogenous cortisol synthesis, since steroid monotherapy has not been shown to be effective in IMN. Moreover, ACTH therapy can be effective even in patients who are unresponsive to steroids. On the other hand, the endogenous cortisol liberated by the actions of exogenous ACTH might act differently and perhaps more effectively than orally administered steroids.

\section{Sirolimus}

The role of sirolimus in IMN has been evaluated in two small pilot studies, with unfavorable results. ${ }^{90,91}$ Austin et al. ${ }^{90}$ studied the effects of sirolimus in nine patients with IMN and high-grade proteinuria (mean $11.9 \mathrm{~g}$ per day). No remissions occurred during therapy, but one patient achieved a partial remission after cessation of therapy. Severe adverse events, including pneumonitis, infection, persistent proteinuria and azotemia, necessitated discontinuation of the drug in the majority of cases. This trial was prematurely terminated owing to the unfavorable risk-benefit ratio. Fervenza et al. ${ }^{91}$ had previously conducted an open-label trial of sirolimus in 11 patients with a variety of chronic glomerulopathies and declining renal function, including three with membranous nephropathy. Treatment was associated with 
acute kidney injury in more than half of the patients; this event generally occurred within weeks of starting sirolimus. Thus, sirolimus does not seem to have a role in the treatment of IMN.

\section{Conclusions}

Cytotoxic agents and calcineurin inhibitors are the most extensively studied agents for the treatment of IMN. Nevertheless, rituximab, ACTH and MMF might have a role in the management of this disease and are appealing options in view of their lack of toxic gonadal, bladder and renal effects. In the future, adequately powered, prospective, randomized studies should compare such alternative agents to standard therapy rather than to placebo, to provide more convincing information about optimal therapy. Unfortunately, as is true for many of the glomerular diseases, randomized controlled trials are difficult to conduct in IMN because of the rarity of the disease and the need to have prolonged follow-up to assess the effect of treatment on renal survival. Up to date information regarding new and ongoing clinical trials in IMN can be found at http://www.clinicaltrials.gov.

Meanwhile, progress continues to be made towards elucidation of the pathogenesis of IMN, including identification of the pathogenic autoantigens. ${ }^{92-94}$ Hopefully, an improved understanding of the disease will facilitate the development of targeted therapy to directly modulate the immune process and inhibit disease progression.

Review criteria
Articles were identified from PubMed using the
search terms "idiopathic membranous nephropathy"
and "treatment" in various combinations with
"cyclophosphamide", "chlorambucil", "ACTH",
"rituximab", "tacrolimus", "cyclosporine",
"mycophenolate mofetil", "azathioprine" and "sirolimus".
Relevant abstracts from the most recent meetings of the
American Society of Nephrology were also reviewed. Only
material published in English was considered.

1. Schena, F. P. Survey of the Italian Registry of Renal Biopsies. Frequency of the renal diseases for 7 consecutive years. The Italian Group of Renal Immunopathology. Nephrol. Dial. Transplant. 12, 418-426 (1997).

2. Haas, M., Meehan, S. M., Karrison, T. G. \& Spargo, B. H. Changing etiologies of unexplained adult nephrotic syndrome: a comparison of renal biopsy findings from 1976-1979 and 19951997. Am. J. Kidney Dis. 30, 621-631 (1997).

3. Glassock, R. J. Secondary membranous glomerulonephritis. Nephrol. Dial. Transplant. 7 (Suppl. 1), 64-71 (1992).

4. Cattran, D. Management of membranous nephropathy: when and what for treatment. J.Am Soc. Nephrol. 16, 1188-1194 (2005).

5. Passerini, P. \& Ponticelli, C. Corticosteroids, cyclophosphamide, and chlorambucil therapy of membranous nephropathy. Semin. Nephrol. 23, 355-361 (2003).

6. du Buf-Vereijken, P. W., Branten, A. J. \& Wetzels, J. F. Idiopathic membranous nephropathy: outline and rationale of a treatment strategy. Am. J. Kidney Dis. 46, 1012-1029 (2005).

7. [No authors listed] A controlled study of shortterm prednisone treatment in adults with membranous nephropathy. Collaborative Study of the Adult Idiopathic Nephrotic Syndrome. N. Engl. J. Med. 301, 1301-1306 (1979).

8. Donadio, J. V. Jr et al. Idiopathic membranous nephropathy: the natural history of untreated patients. Kidney Int. 33, 708-715 (1988).

9. Cattran, D. C. et al. A randomized controlled trial of prednisone in patients with idiopathic membranous nephropathy. N. Engl. J. Med. 320, 210-215 (1989).

10. Cameron, J. S., Healy, M. J. \& Adu, D. The Medical Research Council trial of short-term highdose alternate day prednisolone in idiopathic membranous nephropathy with nephrotic syndrome in adults. The MRC Glomerulonephritis Working Party. Q. J. Med. 74, 133-156 (1990).

11. Cattran, D. C., Pei, Y. \& Greenwood, C. Predicting progression in membranous glomerulonephritis. Nephrol. Dial. Transplant. 7 (Suppl. 1), 48-52 (1992).
12. Schieppati, A. et al. Prognosis of untreated patients with idiopathic membranous nephropathy. N. Engl. J. Med. 329, 85-89 (1993).

13. Ponticelli, C. et al. A 10-year follow-up of a randomized study with methylprednisolone and chlorambucil in membranous nephropathy. Kidney Int. 48, 1600-1604 (1995).

14. Hogan, S. L., Muller, K. E., Jennette, J. C. \& Falk, R. J. A review of therapeutic studies of idiopathic membranous glomerulopathy. Am. J. Kidney Dis. 25, 862-875 (1995).

15. Moranne, O., Watier, L., Rossert, J. \& Stengel, B. Primary glomerulonephritis: an update on renal survival and determinants of progression. QJM 101, 215-224 (2008)

16. Bellomo, R. \& Atkins, R. C. Membranous nephropathy and thromboembolism: is prophylactic anticoagulation warranted? Nephron 63, 249-254 (1993).

17. Ordonez, J. D., Hiatt, R. A., Killebrew, E. J. \& Fireman, B. H. The increased risk of coronary heart disease associated with nephrotic syndrome. Kidney Int. 44, 638-642 (1993).

18. Branten, A. J. et al. Urinary excretion of $\beta 2-$ microglobulin and lgG predict prognosis in idiopathic membranous nephropathy: a validation study. J. Am. Soc. Nephrol. 16 , 169-174 (2005).

19. Bazzi, C. et al. Urinary excretion of IgG and $\alpha(1)$ microglobulin predicts clinical course better than extent of proteinuria in membranous nephropathy. Am. J. Kidney Dis. 38, 240-248 (2001).

20. Cattran, D. C. et al. Validation of a predictive model of idiopathic membranous nephropathy: its clinical and research implications. Kidney Int. 51, 901-907 (1997).

21. Pei, Y., Cattran, D. \& Greenwood, C. Predicting chronic renal insufficiency in idiopathic membranous glomerulonephritis. Kidney Int. $\mathbf{4 2}$, 960-966 (1992).

22. Branten, A. J., Reichert, L. J., Koene, R. A. \& Wetzels, J. F. Oral cyclophosphamide versus chlorambucil in the treatment of patients with membranous nephropathy and renal insufficiency. QJM 91, 359-366 (1998).
23. du Buf-Vereijken, P. W., Branten, A. J., Wetzels, J. F. \& Membranous Nephropathy Study Group. Cytotoxic therapy for membranous nephropathy and renal insufficiency: improved renal survival but high relapse rate. Nephrol. Dial. Transplant. 19, 1142-1148 (2004).

24. Hofstra, J. M., Branten, A. J. W. \& Wetzels, J. F. M. No benefit of early start of immunosuppressive therapy in idiopathic membranous nephropathy [abstract]. J. Am. Soc. Nephrol. 19, 60A (2008).

25. Black, D. A., Rose, G. \& Brewer, D. B. Controlled trial of prednisone in adult patients with the nephrotic syndrome. Br. Med. J. 3, 421-426 (1970).

26. Perna, A. et al. Immunosuppressive treatment for idiopathic membranous nephropathy: a systematic review. Am. J. Kidney Dis. 44 385-401 (2004).

27. Ponticelli, C. et al. A randomized trial of methylprednisolone and chlorambucil in idiopathic membranous nephropathy. N. Engl. J. Med. 320, 8-13 (1989).

28. Ponticelli, C. et al. Controlled trial of methylprednisolone and chlorambucil in idiopathic membranous nephropathy. N. Engl. J. Med. 310, 946-950 (1984).

29. Jha, V. et al. A randomized, controlled trial of steroids and cyclophosphamide in adults with nephrotic syndrome caused by idiopathic membranous nephropathy. J. Am. Soc. Nephrol. 18, 1899-1904 (2007).

30. Reichert, L. J., Huysmans, F. T., Assmann, K., Koene, R. A. \& Wetzels, J. F. Preserving renal function in patients with membranous nephropathy: daily oral chlorambucil compared with intermittent monthly pulses of cyclophosphamide. Ann. Intern. Med. 121, 328-333 (1994).

31. Ponticelli, C., Zucchelli, P., Passerini, P. \& Cesana, B. Methylprednisolone plus chlorambucil as compared with methylprednisolone alone for the treatment of idiopathic membranous nephropathy. The Italian Idiopathic Membranous Nephropathy Treatment Study Group. N. Engl. J. Med. 327, 599-603 (1992). 
32. Ponticelli, C. et al. A randomized study comparing methylprednisolone plus chlorambucil versus methylprednisolone plus cyclophosphamide in idiopathic membranous nephropathy. J. Am. Soc. Nephrol. 9, 444-450 (1998).

33. Falk, R. J., Hogan, S. L., Muller, K. E. \& Jennette, J. C. Treatment of progressive membranous glomerulopathy. A randomized trial comparing cyclophosphamide and corticosteroids with corticosteroids alone. The Glomerular Disease Collaborative Network. Ann. Intern. Med. 116, 438-445 (1992).

34. Branten, A. J. \& Wetzels, J. F. Short- and longterm efficacy of oral cyclophosphamide and steroids in patients with membranous nephropathy and renal insufficiency. Study Group. Clin. Nephrol. 56, 1-9 (2001).

35. Jindal, K., West, M., Bear, R. \& Goldstein, M. Long-term benefits of therapy with cyclophosphamide and prednisone in patients with membranous glomerulonephritis and impaired renal function. Am. J. Kidney Dis. 19, 61-67 (1992)

36. West, M. L., Jindal, K. K., Bear, R. A. \& Goldstein, M. B. A controlled trial of cyclophosphamide in patients with membranous glomerulonephritis. Kidney Int. 32, 579-584 (1987).

37. Bruns, F. J., Adler, S., Fraley, D. S. \& Segel, D. P. Sustained remission of membranous glomerulonephritis after cyclophosphamide and prednisone. Ann. Intern. Med. 114, 725-730 (1991).

38. Faurschou, M. et al. Malignancies in Wegener's granulomatosis: incidence and relation to cyclophosphamide therapy in a cohort of 293 patients. J. Rheumatol. 35, 100-105 (2008).

39. Hoffman, G. S. et al. Wegener granulomatosis: an analysis of 158 patients. Ann. Intern. Med. 116, 488-498 (1992).

40. Cattran, D. C. et al. Cyclosporine in patients with steroid-resistant membranous nephropathy: a randomized trial. Kidney Int. 59, 1484-1490 (2001).

41. Cattran, D. C. et al. A controlled trial of cyclosporine in patients with progressive membranous nephropathy. Canadian Glomerulonephritis Study Group. Kidney Int. 47, 1130-1135 (1995).

42. Rostoker, G. et al. Long-term cyclosporin A therapy for severe idiopathic membranous nephropathy. Nephron 63, 335-341 (1993).

43. Fritsche, L. et al. Treatment of membranous glomerulopathy with cyclosporin A: how much patience is required? Nephrol. Dial. Transplant. 14, 1036-1038 (1999).

44. Ambalavanan, S., Fauvel, J. P., Sibley, R. K. \& Myers, B. D. Mechanism of the antiproteinuric effect of cyclosporine in membranous nephropathy. J. Am. Soc. Nephrol. 7, 290-298 (1996).

45. Guasch, A., Suranyi, M., Newton, L., Hall, B. M. \& Myers, B. D. Short-term responsiveness of membranous glomerulopathy to cyclosporine. Am. J. Kidney Dis. 20, 472-481 (1992).

46. DeSanto, N. G., Capodicasa, G. \& Giordano, C. Treatment of idiopathic membranous nephropathy unresponsive to methylprednisolone and chlorambucil with cyclosporin. Am. J. Nephrol. 7, 74-76 (1987).

47. Yao, X. et al. Cyclosporin A treatment for idiopathic membranous nephropathy. Chin. Med. J. (Engl.) 114, 1305-1308 (2001).

48. Goumenos, D. S. et al. Corticosteroids and ciclosporin A in idiopathic membranous nephropathy: higher remission rates of nephrotic syndrome and less adverse reactions than after traditional treatment with cytotoxic drugs. Am. J. Nephrol. 27, 226-231 (2007).

49. Goumenos, D. S., Kalliakmani, P., Tsakas, S., Sotsiou, F. \& Vlachojannis, J. G. The remission of nephrotic syndrome with cyclosporin treatment does not attenuate the progression of idiopathic membranous nephropathy. Clin. Nephrol. 61, 17-24 (2004).

50. Alexopoulos, E., Papagianni, A., Tsamelashvili, M., Leontsini, M. \& Memmos, D. Induction and long-term treatment with cyclosporine in membranous nephropathy with the nephrotic syndrome. Nephrol. Dial. Transplant. 21, 3127-3132 (2006).

51. Goumenos, D. S. What have we learned from the use of ciclosporin A in the treatment of nephrotic patients with idiopathic membranous nephropathy? Expert Opin. Pharmacother. 9, 1695-1704 (2008)

52. Cattran, D. C. et al. Cyclosporin in idiopathic glomerular disease associated with the nephrotic syndrome: workshop recommendations. Kidney Int. 72, 1429-1447 (2007).

53. Praga, M., Barrio, V., Juárez, G. F., Luño, J. \& Grupo Español de Estudio de la Nefropatía Membranosa. Tacrolimus monotherapy in membranous nephropathy: a randomized controlled trial. Kidney Int. 71, 924-930 (2007).

54. Ballarin, J. et al. Treatment of idiopathic membranous nephropathy with the combination of steroids, tacrolimus and mycophenolate mofetil: results of a pilot study. Nephrol. Dial. Transplant. 22, 3196-3201 (2007).

55. Li, X. et al. Early initiation of tacrolimus or cyclophosphamide therapy for idiopathic membranous nephropathy with severe proteinuria. J. Nephrol. 21, 584-591 (2008)

56. Jardine, A. G. Assessing the relative risk of cardiovascular disease among renal transplant patients receiving tacrolimus or cyclosporine. Transpl. Int. 18, 379-384 (2005).

57. Artz, M. A. et al. Conversion from cyclosporine to tacrolimus improves quality-of-life indices, renal graft function and cardiovascular risk profile. Am. J. Transplant. 4, 937-945 (2004).

58. Knoll, G. A. \& Bell, R. C. Tacrolimus versus cyclosporin for immunosuppression in renal transplantation: meta-analysis of randomised trials. BMJ 318, 1104-1107 (1999).

59. Ponticelli, C. \& Villa, M. Does cyclosporin have a role in the treatment of membranous nephropathy? Nephrol. Dial. Transplant. 14, 23-25 (1999).

60. Miller, G., Zimmerman, R. 3rd, Radhakrishnan, J. \& Appel, G. Use of mycophenolate mofetil in resistant membranous nephropathy. Am. J. Kidney Dis. 36, 250-256 (2000).

61. Choi, M. J. et al. Mycophenolate mofetil treatment for primary glomerular diseases. Kidney Int. 61, 1098-1114 (2002).

62. Polenakovic, M., Grcevska, L. \& Dzikova, S Mycophenolate mofetil in treatment of idiopathic stages III-IV membranous nephropathy. Nephrol. Dial. Transplant. 18 1233-1234 (2003).

63. Sahin, G. M., Sahin, S., Kantarci, G. \& Ergin, H Mycophenolate mofetil treatment for therapyresistant glomerulopathies. Nephrology (Carlton) 12, 285-288 (2007).

64. Senthil Nayagam, L. et al. Mycophenolate mofetil or standard therapy for membranous nephropathy and focal segmental glomerulosclerosis: a pilot study. Nephrol. Dial. Transplant. 23, 1926-1930 (2008).

65. Segarra, A. et al. Efficacy and safety of 'rescue therapy' with mycophenolate mofetil in resistant primary glomerulonephritis-a multicenter study. Nephrol. Dial. Transplant. 22, 1351-1360 (2007).

66. Chan, T. M. et al. Prospective controlled study on mycophenolate mofetil and prednisolone in the treatment of membranous nephropathy with nephrotic syndrome. Nephrology (Carlton) 12, 576-581 (2007).

67. Branten, A. J., du Buf-Vereijken, P. W. Vervloet, M. \& Wetzels, J. F. Mycophenolate mofetil in idiopathic membranous nephropathy: a clinical trial with comparison to a historic control group treated with cyclophosphamide. Am. J. Kidney Dis. 50, 248-256 (2007).

68. Dussol, B. et al. Mycophenolate mofetil monotherapy in membranous nephropathy: a 1-year randomized controlled trial. Am. J. Kidney Dis. 52, 699-705 (2008).

69. Chan, T. M. et al. Efficacy of mycophenolate mofetil in patients with diffuse proliferative lupus nephritis. Hong Kong-Guangzhou Nephrology Study Group. N. Engl. J. Med. 343, 1156-1162 (2000).

70. Rivera, T. L. Current therapies for lupus nephritis in an ethnically heterogeneous cohort. J. Rheumatol. 36, 298-305 (2009).

71. Yau, W. P., Vathsala, A., Lou, H. X. \& Chan, E. Is a standard fixed dose of mycophenolate mofetil ideal for all patients? Nephrol. Dial. Transplant. 22, 3638-3645 (2007).

72. Shiiki, H. et al. Prognosis and risk factors for idiopathic membranous nephropathy with nephrotic syndrome in Japan. Kidney Int. 65, 1400-1407 (2004).

73. Baker, L. R., Tucker, B., Macdougall, I. C. \& Oommen, R. Treatment of progressive renal failure and nephrotic syndrome with azathioprine and prednisolone. Postgrad. Med. J. 73, 647-648 (1997)

74. Brown, J. H. et al. Treatment of renal failure in idiopathic membranous nephropathy with azathioprine and prednisolone. Nephrol. Dial. Transplant. 13, 443-448 (1998).

75. Williams, P. S. \& Bone, J. M. Immunosuppression can arrest progressive renal failure due to idiopathic membranous glomerulonephritis. Nephrol. Dial. Transplant. 4 181-186 (1989)

76. Goumenos, D. S., Ahuja, M., Davlouros, P., El Nahas, A. M. \& Brown, C. B. Prednisolone and azathioprine in membranous nephropathy: a 10-year follow-up study. Clin. Nephrol. 65, 317-323, (2006).

77. Remuzzi, G. et al. Rituximab for idiopathic membranous nephropathy. Lancet $\mathbf{3 6 0}$, 923-924 (2002)

78. Ruggenenti, P. et al. Rituximab in idiopathic membranous nephropathy: a one-year prospective study. J. Am. Soc. Nephrol. 14, 1851-1857 (2003).

79. Ruggenenti, P. et al. Role of remission clinics in the longitudinal treatment of CKD. J. Am. Soc. Nephrol. 19, 1213-1224 (2008).

80. Fervenza, F. C. et al. Rituximab treatment of idiopathic membranous nephropathy. Kidney Int. 73, 117-125 (2008)

81. Cravedi, P., Ruggenenti, P., Sghirlanzoni, M. C. \& Remuzzi, G. Titrating rituximab to circulating B cells to optimize lymphocytolytic therapy in idiopathic membranous nephropathy. Clin. J. Am. Soc. Nephrol. 2, 932-937 (2007). 
82. Ruggenenti, P. et al. Rituximab for idiopathic membranous nephropathy: who can benefit? Clin. J. Am. Soc. Nephrol. 1, 738-748 (2006).

83. Cobo, M., Hernández, D., Rodriguez, C. \& Pérez-Tamajón, L. Successful therapeutic use of rituximab in refractory membranous glomerulonephritis. Clin. Nephrol. 66, 54-57 (2006).

84. Ruggenenti, P. et al. Effects of rituximab on morphofunctional abnormalities of membranous glomerulopathy. Clin. J. Am. Soc. Nephrol. 3, 1652-1659 (2008).

85. Garjau, M. et al. Efficacy of combined therapy with rituximab and tacrolimus in the induction of stable remission of proteinuria in patients with primary membranous glomerulonephritis [abstract]. J. Am. Soc. Nephrol. 19, 561A (2008).

86. Berg, A. L., Nilsson-Ehle, P. \& Arnadottir, M. Beneficial effects of ACTH on the serum lipoprotein profile and glomerular function in patients with membranous nephropathy. Kidney Int. 56, 1534-1543 (1999).

87. Berg, A. L. \& Arnadottir, M. ACTH-induced improvement in the nephrotic syndrome in patients with a variety of diagnoses. Nephrol. Dial. Transplant. 19, 1305-1307 (2004).

88. Picardi, L. et al. ACTH therapy in nephrotic syndrome induced by idiopathic membranous nephropathy. Clin. Nephrol. 62, 403-404 (2004).

89. Ponticelli, C. et al. A randomized pilot trial comparing methylprednisolone plus a cytotoxic agent versus synthetic adrenocorticotropic hormone in idiopathic membranous nephropathy. Am. J. Kidney Dis. 47, 233-240 (2006).

90. Austin, H. A., Braun, M. J., Howard, L. V., Kopp, J. B. \& Balow, J. B. Sirolimus therapy in idiopathic and lupus membranous nephropathy [abstract]. J. Am. Soc. Nephrol. 19, 561A (2008).

91. Fervenza, F. C. et al. Acute rapamycin nephrotoxicity in native kidneys of patients with chronic glomerulopathies. Nephrol. Dial. Transplant. 19, 1288-1292 (2004).

92. Debiec, H. et al. Antenatal membranous glomerulonephritis due to anti-neutral endopeptidase antibodies. N. Engl. J. Med. 346, 2053-2060 (2002).

93. Ronco, P. \& Debiec, H. Target antigens and nephritogenic antibodies in membranous nephropathy: of rats and men. Semin. Immunopathol. 29, 445-458 (2007).

94. Beck, L. et al. Discovery of the phospholipase A2 receptor as the target antigen in idiopathic membranous nephropathy [abstract]. J. Am. Soc. Nephrol. 19, 104A (2008).

\section{Acknowledgments}

The authors are grateful to Drs James Balow and

Monique Cho for their critical reading of this

manuscript. This work was supported by the

Intramural Research Program of the National Institute of Diabetes and Digestive and Kidney Diseases, NIH. 